\title{
USING GOVERNMENT LAWYERS TO ANIMATE BUREAUCRACY
}

\author{
RAYMOND P. BALDWINT and LIVIRGSTON HALL TิTे
}

A BASIC flaw in governmental organization is the lack of adequate means of communication. A new administration comes into office determined to carry out policies which during the campaign seemed to be the simple cure of evils besetting the country. Once in the White House, the president finds that the appointment of able and responsive top personnel is not enough. For the work of Government must be carried out by more than two million career employees, protected in their jobs by civil service legislation. Unless new policies can be communicated to them, and methods are found to translate these policies into action, the executive branch of the Government is like a man with a new head which is not yet in touch with the various parts of his body. It is half-paralyzed. Its "head" tells its "hand" to pick up a pencil and write a certain message; but it gets no response, because there is no nerve connection between mind and hand. According to a high oficial of the present administration, his Department is still hampered by this condition.

Properly organized, instructed and supervised, the lawyers in Government can help to correct this flaw. They can enable a president to put his policies into practice, and at the same time make federal bureaucracy more efficient. A Government lawyer can allow himself to become lost in the channels of bureaucratic machinery, moving only according to fixed rules, and imposing legal restraint upon his administrative colleagues. Or he can remain freewith that independence of thought and spirit which lawyers share with taxi drivers-and find ways to facilitate action rather than to restrain it. The lawyer, if he will but maintain his independence, can be the unspoiled civilian in Government. Because he has no administrative duties, he can observe the bureaucratic machinery from a sort of catwalk; and because of the freemasonry of his profession he can communicate freely with other Government lawyers. MIoreover, he can see that high policy decisions are put into effect at the important working level, and he can help coordinate the work of his own agency with that of other agencies of the Government. Coordination is particularly important in periods of political transition, and when task-force operations become necessary in a national emergency. The effectiveness of the individual lawyer in contributing to such coordination will depend largely on the organization of the Office of General Counsel.

$\doteqdot$ iBoston Regional Counsel, Renegotiation Board.

ii Vice Dean, Harvard Law School. 


\section{The Offices of General Counsel.}

The formal duties of a member of the legal staff of an executive agency differ with each agency and with each grade within that agency. In general, however, each lawyer serves on the staff of a General Counsel, the chicf legal officer of each agency who is sometimes designated as the Legal Advisor or Solicitor. The stated duties of an Office of General Counsel include: (1) providing interpretative legal advice on all phases of the agency's day-today activities, both to the agency and to the public; (2) processing forms filed with the agency; (3) drafting contracts, orders and other legal doct1ments; (4) rendering legal opinions; (5) representing the agency in negotiations with private individuals and corporations, and with other agencies of the Government; (6) representing the agency in court and before quasijudicial boards and commissions; (7) preparing and reviewing administrative rules, regulations and reports, and drafting proposed legislation; and (8) participating in the policy-making process of the agency. ${ }^{1}$ Such a formal categorization nowhere suggests that the great unstated duty and opportunity of the legal staff is to afford an informal means of rapid communication throughout a particular agency, and between it and other agencies.

Here we are concerned not so much with how lawyers clo in fact now function in all departments and other executive agencies of the Government, as with ways in which lawyers in Government agencies can help to make those agencies operate more smoothly and get their jobs done more efficiently. The methods to be described below have been used to a limited extent, but with outstanding success, by some agencies; and their use fortunately appears to be increasing.

Crucial to the success of the proposed function of lawyers in Government is the proper relationship between the administrative head of an agency and his General Counsel. The administrative head of the agency must first understand, and then want what his General Counsel's Office might be able to do for his agency. Furthermore, he must have a General Counsel who not only understands these opportunities for service, but who also has a detailed plan of how to organize and train his staff to actuate agency policies. This may be easy if the administrator has chosen his General Counsel with such an end in view. ${ }^{2}$ But where the plan originates with the legal staff, the General Counsel may have to "sell" it to the administrator, to say nothing of selling it throughout the agency. If the administrator is in any doubt about the desirability of the plan, he must be convinced that the General Counsel will be loyal to him through thick and thin, keeping him fully informed of what is going on throughout the agency, and carrying his policies and those

1. See, Ford, The Governurent Lawyer: A Survey and Analysis of Lawyens in the Executive Branch of the United States Governitent (1952).

2. See Neale, Naval Procurement During World War II: Its Legal Aspects, 38 A.B.A.J. 213 (1952). 
of the Administration down to the working units of the organization. This loyalty to the administrator raises problems at lower levels; but none, as will be seen, which are insurmountable.

Once a plan for training and organizing legal personnel is in operation, each General Counsel should be in close daily touch with the administrative head of his agency. For this purpose, it is desirable to have the quarters of the General Counsel adjoin those of the administrator. The General Counsel should be fully informed of the policies of the agency on all questions of importance at all times. He should participate in the determination of those policies. To make his participation in policy-making of the greatest value, he and his staff should also keep themselves informed of the policies of the Administration through contacts with the White House and other administrative agencies. Within each General Counsel's office, or readily accessible to it, should be the headquarters personnel required for legal research, drafting and interpretation of legislation and regulations, and the preparation of contracts and other documents. The rest of the legal personnel should be assigned to strategic points in the administrative organization, for the purpose of improving intra-agency communication.

\section{InTRA-Agency CoMarunication}

The organization chart contributes most to present delay and inefficiency in Government. At birth each federal executive agency and department acquires one of these charts. The name of the department or agency appears at the top of the typical chart. Below is a box for the administrative head of the agency. From him runs a vertical line through a horizontal line, from which suspend designations of the offices or officers of his immediate staff, to another horizontal line which indicates the administrator's authority over his immediate administrative subordinates. The chart then proceeds like a family tree, with the administrator as Father Abraham, and the administrator's authority, like Abraham's seed, being carried down, subdivided and carried farther down, until it has shown the administrative level and channel of authority of every person in the agency.

For purposes of job description and the determination of rates of pay such a chart is no doubt useful. When insisted upon, as it usually is, as a pattern of normal functional activity, it is frequently a source of frustration and inefficiency, stifling initiative and causing inexcusable delay. An official on the working level may have a problem requiring consultation with another official in the same agency, on the same level, in the same building, even in the same room. If they could discuss the problem freely a decision might be reached in five minutes. Instead, the man with the problem must write a memorandum, route it through his immediate superior in the hierarchy; then through this superior to his superior in turn, and so on up until it finally reaches the common superior of the two men who might have talked together. 
It must then find its way down through channels, until it finally renches its working level recipient. The memorandum may get stuck at any point, because one official in the chain is behind in his work or in cloubt as to his duty. And it may take days, weeks, or even months for the initiating official to get a reply.

By occupying a position outside the administrative hierarchy, the legal staff of an agency, if properly organized, can overcome many of the bottlenecks and delays inherent in the organization chart. To achieve this result, legal personnel-and this is the nub of the overall plan-should be assigned to parallel closely the active working units of the administrative organization which they are to serve. They should constitute a network of communication throughout the agency, not unlike the nervous system of the human body. If the lawyer assigned to an administrative unit has the conficlence of the chief and other members of that unit, they will come to him for help when they need it. And through the communications center-the General Counsel's Office-where one lawyer may talk with another directly, the fault can be quickly located and remedied.

These lawyers, each of whom should be sitting at the elbow of an administrative officer, must be chosen with care. Their patience and tact will largely determine the effectiveness of the entire plan. For in Government, as in business, lawyers are not inherently popular. And bureaucrats, like businessmen, resent any suggestion that lawyers are trying to run things. But in Government, as in business, the lawyer who is willing to subordinate his ego to his cause can get things done. These working-level lawyers must overcome the suspicion that they are part of a spy system for the administrator. By loyalty to the administrative unit which he serves, each must gain the cooperation of its head and of every person on that unit's staff. And he must make himself so useful that he is wanted and used. ${ }^{3}$

For the plan to work, every member of the agency's personnel who is responsible for any act of the agency should have ready access to counsel. He should be made to feel that he can consult frankly and, if necessary, confidentially with the lawyer assigned to his department, branch, division, section, or other unit. The working-level administrative subordinate frequently knows, or thinks he knows, better than his boss. Under the present system he is often unable to have his views, right or wrong, considered, because of adher" ence to the rigid formalities of the organization chart. His immediate superior says no; and there they stop. Working-level counsel should hear his views. If they are right, they can be conveyed to the General Counsel, and the immediate superior can then be informed from above, without embarrassment. If the subordinate is wrong, working-level counsel can nevertheless

3. For an excellent analysis of the lawyer's function in Government, see Willcox, The Lawyer in the Administration of Nonregulatory Programs, 13 PUB. Adsin. Rev. 12 (Winter, 1953). 
secure his more willing cooperation by explaining to him the policy reasons for his superior's stand.

An example of improved intra-agency communication began early in World War II. James Forrestal, then Under Secretary of the Navy, insisted upon taking an active part in the procurement of armaments and supplies, an activity which was under his general jurisdiction. He found that the normal channels of communication within the Navy hierarchy were not adapted to keeping him cognizant of what was taking place at the operating level. To remedy this, he appointed $\mathrm{H}$. Struve Hensel, ${ }^{*}$ an outstanding civilian lawyer, as General Counsel. Hensel set up a legal office composed entirely of civilian lawyers to serve those engaged in the business functions of the Navy. Under him were bureau counsel for each of the technical bureaus. These bureau counsel, some one hundred lawyers, handled matters arising out of the procurement and fiscal functions of the Navy, and also served, though not ostensibly, to keep the Under Secretary fully informed at all times as to what was going on at all levels.

At first, Navy procurment officers, as well as the lawyers in the office of the Judge Advocate General of the Navy, resented the intrusion of these civilian lawyers. The procurement officers objected to what they considered the lawyer's divided loyalty-to themselves, and to the Under Secretary of the Navy. As time went on, however, they came to rely more and more on the lawyers at their elbows. What was a wartime innovation is now a recognized part of the Navy's procurement program. 5

The Navy's methods of organizing its Office of General Counsel are being adopted by the Air Force. ${ }^{6}$ And there are advocates for its full adoption by the Army, although its development in the Department of the Army is retarded by existing statutory provisions which make the Army's Judge Advocate General the chief legal officer of that Department. ${ }^{7}$ Acceptance by the armed services of the civilian lawyer's role is a big step forward in intraagency efficiency. Its adoption by other agencies will depend upon recognition of its value by the administrators of those agencies and by the men appointed as their General Counsel.

Where the agency has regional offices, a similar setup is necessary for the proper integration of the agency as a whole. The wartime Boston Regional Office of the Office of Price Administration is a good example of such an operation. The entire range of commodities handled by the O.P.A. was divided among twelve to fifteen "commodity men" who were not lawyers. Five or six lawyers handled the same range, and each lawyer had his desk in the midst of the two or three "commodity men" who handled the same

4. Now General Counsel of the Department of Defense.

5. See Neale, supra note 2.

6. Vorenberg, The Office of General Coumsel of the Air Forie, Hunwaw Law Stnogh Burl. (June, 1953).

7. 10 U.S.C. $\$ \S 61-3(1946)$. 
products as he. All were on common telephone extensions, had access to the same reference books bearing on their specialties, and could hear everything that each said to anyone else. This physical proximity soon got them working together as a team; and teamwork was sometimes facilitated by the initial mistakes made by "commodity men" who later learned to consult their lawyers. Close physical proximity may not always be necessary. Nevertheless, a parallel system of organization is essential, and proximity has been found advantageous in making the system successful.

The number of lawyers needed to integrate the operations of an agency is very small compared with the number of administrative personnel. Naturally, it will vary with the nature of the agency's activities. It will be proportionately less in a self-contained, old-line agency, such as the Post Office Department, and more in a relatively new agency, like the Atomic Energy Commission, which must have daily contact with many other branches of the Government. It may run from as few as one lawyer for every seven hundred administrative workers to as many as one for every two hundred, it mere one-half of one percent.

The concept of a legal staff operating as a network of communication within an agency will remain only a concept if it is not implemented by the desire and determination of the General Counsel to make it work. The plan must be a matter of affirmative policy; it must be followed up by positive instructions to, and education of, the members of the legal staff; and it must be under constant and concerned supervision. If the Government lawyer is to help put high policies into action, each General Counsel must make sure that every member of his staff knows just what these policies are. Similarly, every working-level member of his staff must be able to communicate to the General Counsel any difficulty he may encounter, together with his suggestions for its correction.

If the proper relationship is established between the General Counsel and the lawyers on his staff, both in Washington and in the field, advice will not always be a one-way street. The working-level lawyer, because of his proximity to practical operations of that part of the agency to which he is assigned, can often suggest to the General Counsel modifications of rulings and procedures which will facilitate a smoother functioning of the organization as a whole. By making the requirements of the agency more understandable and thus more acceptable, the lawyer can improve the agency's relations with businessmen and others with whom it is dealing. Yet obviously, if the staff is large it it not practical to permit every lawyer to walk unannounced into the General Counsel's private office. However, there should be the same feeling of free informality that is found in a private law office, and an assurance that if a subordinate himself is unable to bring every problem directly to his General Counsel, his problem will nevertheless be handled on a personal basis, and promptly placed before the General Counsel if that is necessary. If considerations of protocol and the snobbishness of hierarcliy 
are permitted to invade the legal organization, it will be a hindrance rather than a help to the administrative agency which it is intended to serve. Actions will have to await the advice of counsel, and the delays inherent in the clearing of opinions through bureaucratic channels are certain to result either in administrative inefficiency or in ad hoc decisions being made on the working level without adequate policy guidance. To avoid this, each General Counsel should strive for informality in the workings of his staff, and, as far as possible, in its dealings with lawyers in other agencies.

\section{INTER-AgENCY COORDINATYON}

Operation of the Government necessitates many inter-agency conferences in Washington and in the field. Some are sporadic; others are regular. Perhaps the most important are the task-force meetings which take place in times of national emergency, when the activities of numerous agencies of the Government must be coordinated to accomplish a specific objective. If the chief of a division or section of an agency must attend an inter-agency meeting, three things are almost sure to happen: (1) he will have been so busy with his administrative duties that he will come to the meeting inadequately briefed on the subject to be discussed; (2) he will fall behind in his administrative duties while attending the meeting and trying to catch up with the interagency problem; and (3) he will then send a subordinate to cover subsequent meetings.

The Government lawyer can help to remedy this situation. In addition to his function as part of a backstage communications system capable of coordinating the activities of his agency, he can act as an advocate for his agency or the administrative unit of that agency to which he is assigned. But the privilege of representing an agency or one of its administrative subdivisions is not automatically acquired by members of the legal staff. First there must be a relationship of mutual confidence built up between the lawyer and the administrative officer whom he is to represent. Their views must agree; they must be able to meet regularly enough to be in complete accord. The lawyer cannot afford to be suspected of trying to run things. He is not the administrative officer, but rather the advocate of the administrative officer. If this is clearly understood, and if the lawyer will talie the same care in his preparation for each meeting as he would in preparing a case for trial, he can probably represent his agency far more effectively than his administrative opposite number could do, and can leave the latter free to carry on the regular business of the agency.

A good example of effective representation is the North African Committee's record during World War II. Thomas K. Finletter, than a Special Assistant to the Secretary of State, organized this Committee to handle civilian supplies to North Africa after Allied troops had landed there. The Committee consisted of representatives of the State Department, Treasury Procurement, 
Lend Lease, Army, Navy, War Shipping Administration, Board of Economic Warfare, Commodity Credit Corporation, U.S. Commercial Corporation, and occasional members from other agencies, as well as two members representing British interests. Most of the American members, and both the Britishers, were lawyers. Each consulted with his administrative counterpart before and after each meeting. Each was briefed on the views and policies of his agency. Each had, or obtained, authority to make decisions. Without interruption of the normal administrative processes of their several agencies, these lawyers presented, and often fought vigorously for, the views of their respective agencies. The North African Committee, though almost devoid of formal authority or bureaucratic orthodoxy, constituted itself a task force, and effectively accomplished its purpose by screening requests from North Africa for supplies, then getting the necessary supplies to their destination.

To cite the success of this wartime Committee is not to belittle the diffict1ties of establishing proper inter-agency coordination. Lawyers in Washington still have the problem of finding means to provide inter-agency communicttion and cooperation at all levels. This is not easy, because the chief of a division in one department is usually bureaucratically unwilling to have someone in another agency tell his subordinate what to do. Where he is represented by a lawyer outside the administrative hierarchy, this unwillingness will frequently give way to thankfuiness for being relieved of the responsibility. It should be this lawyer's job to devise ways of establishing inter-agency communication through the lawyers of other agencies, and of injecting high level policy into inter-agency dealings without stepping on bureaucratic toes.

In such a fashion the lawyer in Government can function as an intelligence at a point of action, in unhampered contact with other lawyers throughout the Government, bringing into our inescapable bureaucracy the quick means of communication necessary to make the executive branch an organization of integrated harmony and effectiveness. 


\section{THE YALE LAW JOURNAL}

VolUMe 63 DECEMBER, 1953 NUMBer 2

\section{EDITORIAL BOARD}

DAVID R HyoE

Editor-in-Chicf

\section{RICHARD A. SIEGAL Article and Book Review Editor}

WIIIIAXY BARONOFF ROBERT WM. BEREND Richaro K. Berg Múrry David Brochin BARRY $R$ BRYAN Thonjas N. Carruthers, JR. Jeroxie A. Cohen LEwIS G. COLE JoHN W. COLIERAN WIILIAN H. Dearpsey, JR. Russerl C. Dilzs Davio A. Drexier S. GoRDON ELKINS KLAUS EPPLER JoSEPH MI. FIELD
MIARIN Katz

David R. TILLINghast

JoN R. WALtz

Note and Comment Editors

Bernaro Finkelstein JOSEPH B. GILDEN HORN Alin Gladstone Howard Alan Glickstei: Norutan S. Goldsartith Harold Grabino Anne Gross Charles S. Haight, Je. Eldiot Lee Horkatan Alexander P. Hofrarians ROBEET L. LASKY NoEl ARNold LeVtN Charles S. Mieches, Jr. Thonas F. Nelson

diarie Mcdianon Business Secretary
PAysori WolfF Managing Editor

Stuart 1r. Paley Alvin H. Senuzara: JEANהE RutcaIE SILIER Alo:rroe Silverusa: Richand S. Sizsro:ss DArirer MI. Si:ient Gornos: B. Servick: Mfetvix Ster:i DAYm R. ToL StEpHE: W. Tuli: Gerald WaLdi: Roger A. WeLch PAul R. Weltcaer HAROLD MI. IV'IT GEORge C. ZACHARY

\section{CONTRIBUTORS TO THIS ISSUE}

Eugene V. Rostow. B.A. 1933, LL.B. 1937, 11.A. 1944, Yale University. Professor of Law, Yale Law School. Author: A National Policy for the On Irousmy (1948).

Fientivg J Anres, JR. B.A. 1925, LL.B. 1928, Yale University. Lafayette S. Foster Professor of Law, Yale Law School. Co-author: SHularax \& Juxres, Cases ox Tosts (2d ed. 1952).

Lours E. REIK. A.B. 1933, Princeton University; M.D. 1938, University of Pennsylvania. Diplomate, American Board of Neurology and Psychiatry. Psychiatrist, Health Dep't, Princeton University.

Rayarond P. Bazdwin. A.B. 1916, LL.B. 1921, Harvard University. Formerly Chairman, Appeal Board, Office of Contract Settlement. Boston Regional Counsel, Renegotiation Board.

Lrvingston Halz. Ph.B. 1923, University of Chicago; LL.B. 1927, Harvard University. Formerly Boston Regional Price and Enforcement Attorney, Office of Price Administration. Professor of Law and Vice Dean, Harvard Law School. 